Nature would have man isolated, but he triumphs over her with billets of steel and threads of copper. He swings a hammer and an engine is made that makes him neighbor to the world. $\mathrm{He}$ whispers to a wire which shouts the spoken word into space.

Nature would have a limit to the soil's supporting strength, but man robs the air of its nitrogen and the rocks of their phosphorus and potash to revivify the unwilling earth.

Nature would have man the victim of insidious enemies that stop or clog the human machine, but man distills from the buried carbons agents that stay destruction for a time, and now man has found a mineral which gives promise of opening the way into a new world of mysterious restoration.

This is a glorious battle in which you are fighting-the geologist who reads the hieroglyphs that nature has written, the miner who is the Columbus of the world underground, the engineer, the chemist, and the inventor who out of curiosity plus courage, plus imagination fashion the swords of a triumphing civilization. Indeed it is hardly too much to say that the extent of man's domain and his tenure of the earth rest with you.

DEPARTMENT OF THE INTERIOR

$$
\text { F. K. LANE }
$$

\section{DANIEL GIRAUD ELLIOT}

IN the death of Daniel Giraud Elliot, which occurred on December 22 last, after a short illness from pneumonia, science has lost a distinguished ornithologist and mammalogist. Dr. Elliot was born in New York City, March 7, 1835, and had therefore nearly completed his eighty-first year. He prepared to enter Columbia College in the class of 1852, but delicate health prevented his taking a college course and led him to seek for several years a mild winter climate, during which he visited southern Europe, Egypt, Palestine, Turkey, the West Indies and Brazil. In 1906 he was honored by Columbia University with the degree of Sc.D. From an early age his interest in natural history was intense, and in its pursuit he traveled widely and spent many years in Europe, chiefly in Paris and London. For some years before his death he was the dean of American zoologists, exceeding in age his lifelong friend, Dr. Theodore N. Gill, by two years. His primary interest for many years was ornithological, and he was the author of many folio monographs of birds, expensively illustrated with handcolored plates; during the last twenty years he devoted his time to the study of mammals, which became almost exclusively the subject of his researches.

In his early days he formed a notable collection of North American birds-the best private collection then extant-which later was secured by the American Museum of Natural History, forming its first collection of birds and the nucleus of its present magnificent collection. At this time (in the later sixties) George N. Lawrence, a much older man than Elliot, was the only working ornithologist in New York, while John Cassin, of Philadelphia, and Professor S. F. Baird, of Washington, were the only other prominent ornithologists in America.

Dr, Elliot's first publication of note was his "A Monograph of the Tetraonidæ, or Family of the Grouse" (New York, 1864-1865), a work in imperial folio with 27 handcolored plates. This was followed two years later by "A Monograph of the Pittidæ, or Family of the Ant Thrushes" (New York, 1867), also in folio with 31 colored plates. Soon after appeared his "The New and Heretofore Unfigured Species of the Birds of North America" (New York, 1866-1869), in two imperial folio volumes with 72 colored plates. These were soon succeeded by "A Monograph of the Phasianidæ, or Family of Pheasants" (New York, 1872), also in two folio volumes with 49 colored plates. These works, mainly illustrated from his own drawings, were all brought out in America and their preparation marks the period prior to his long sojourn abroad, beginning in 1869 , where similar magnificent works were prepared and published in London. These are: "A Monograph of the Paradiseidæ, or Birds of Paradise" (folio, London, 1873, with 37 colored plates); "A Monograph of the Bucerotidæ, or Hornbills" (folio, London, 1876-1882, with 59 colored plates); “A Mono- 
graph of the Felidæ, or Family of the Cats" (folio, London, 1883, with 43 colored plates). These works were not only important contributions to science but as works of art were at the highest level of such publications and rendered their author famous throughout the world, winning for him many decorations from European governments. He was himself an artist of no ordinary attainments, but he sought for his illustrations the best talent available abroad, including such eminent draughtsmen as Wolf and Keulemans.

During this period of nearly ten years abroad he was a frequent sojourner in Paris, in order to avail himself of the rich treasures of the famous natural history museum of that city, and became thus intimately associated with many of the leading French zoologists. Through his long residence in London he participated in the scientific activities of the British Ornithologists' Union and the Zoological Society, and for a time was a member of the Publication Committee of the latter. In his recent "In Memoriam" of the late Philip Lutley Sclater, ${ }^{1}$ for so many years the efficient secretary of the Zoological Society and also editor of The Ibis, he has given a most enchanting reminiscence of the great naturalists who were in that day at the height of their activities and renown, but who have now, with the single exception of F. Ducane Godman, preceded Elliot to the great beyond.

Although the labor of getting up his great illustrated monographs must have been absorbing, he found time to prepare many technical papers on birds, which were published at frequent intervals in The Ibis or in the Proceedings of the London Zoological Society. At this time he was especially interested in the Trochilidæ, or Hummingbirds, the outcome of which was his "A Classification and Synopsis of the Trochilidæ," a quarto memoir of about 300 pages, with numerous text illustrations, published in the Smithsonian Contributions (Washington, 1879).

Elliot's active temperament never permitted him to remain long idle. Soon after his return from abroad he became one of the au-

1 The Auk, XXXI., January, 1914, pp. 1-12. thors of the "bird volume" of Kingsley's "The Standard Natural History," published in 1885 , to which he contributed the parts on the Gallinæ, the pigeons and the hummingbirds, and also began work on a new edition of his "Monograph of the Pittidæ." Since the publication of the first edition in 1863, the number of species of the group known to science had nearly doubled, and in preparing the new edition the text of the first was wholly discarded, only a few of the plates being retained in the second, which now included 51 colored plates with wholly new and greatly extended text. It was published in London by Quarich (1893-1895).

Another outcome of his long interest in the Trochilidæ was the formation while abroad of a collection of these "gems of ornithology," which he brought with him on his return to New York early in 1883. This collection, then probably unsurpassed by any other, he later (in 1887) presented to the American $\mathbf{M u}$ seum of Natural History, where it has since remained as a standard reference collection for the group. At about this date Dr. Elliot's extensive and well-selected ornithological library passed to the museum by purchase. It contained many rare as well as expensive works, and for the first time the museum came into possession of a reasonably adequate library of ornithology.

In 1894 Elliot became curator of zoology at the Field Columbian Museum at Chicago, from which office he resigned in 1906 and returned to New York. During his curatorship at this institution the zoological department at the Field Museum made rapid strides through his energetic efforts, and it was also a period of marked activity in his literary career. In 1896 he made an expedition to Africa in the interest of this museum, passing through Somaliland and Ogaden on his way to the Boran country, where his work was checked by serious illness. He succeeded, however, in bringing back a large collection of birds and mammals, which became not only the basis of important exhibits in the museum but of important papers giving the results of his explorations. He later made a difficult 
expedition to the Olympic Mountains in Washington, also fruitful in zoological results.

During his curatorship at the Field $\mathrm{Mu}$ seum he prepared and published under its auspices several important handbooks on North American mammals, an undertaking that might well have taxed the courage and energies of a much younger man. These are: "Synopsis of the Mammals of North America and the Adjacent Seas" (1 volume, large 8vo, 1901); "The Land and Sea Mammals of Middle America and the West Indies" (2 vols., large 8vo, 1904); "A Check List of the Mammals of the North American Continent, the West Indies and the Neighboring Seas" (1 vol., 8vo, 1905); "A Catalogue of the Collection of Mammals in the Field Columbian Museum" (large 8vo, 1907). The first two of these works form a handbook to all the mammals of North America and adjacent islands, with the cranial characters of each genus well illustrated by excellent half-tone cuts of natural size, while the text gives brief descriptions and full references to the original descriptions. While open to criticism, as such work must always be, they have proved of great utility not only to amateurs but to experts.

On leaving the Field Museum he set out upon a work of so much difficulty and magnitude that it seemed an almost audacious undertaking, which some of his friends feared would prove beyond his strength. This is his "A Review of the Primates," begun in 1906 and completed in 1912, and published in three volumes by the American Museum of Natural History, with 11 colored plates of animals and 32 half-tone plates of skulls, the latter all natural size, and with a perfection of detail not previously attained. Soon fully realizing the seriousness of the undertaking he sailed for Europe in April, 1907, to visit all of the principal museums abroad in order to study the actual types of the species and such other material as bore upon the subject. After visiting the museums and zoological gardens of Europe he passed on to Egypt, India, China and Japan, returning to New York after an absence of eighteen months, with an immense store of notes and manuscripts for future elaboration. After the work had greatly progressed he found it neeessary to revisit the museums of Europe to settle many still doubtful points. He labored at his great task incessantly for at least nine months of each year, year after year, with indomitable industry and perseverance till at last it was completed for the press. In a work of this nature it would be rash to expect perfection; it is essentially sound in principle and method, and if lacking somewhat in dotails, it will long be of invaluable service to all who may follow in the same field.

Besides the works already mentioned, Dr. Elliot has many lesser volumes and a long list of technical and occasional papers to his credit. During the years 1895-1898, he published three casual volumes, of a somewhat popular character, on the game birds of North America, for Elliot was an ardent sportsman as well as a naturalist. These books, which have met with much favor, are entitled: "North American Shorebirds: a History of the Snipes, Sandpipers, Plovers and their Allies" (8vo, New York, 1895); "The Gallinaceous Game Birds of North America" (8vo, New York, 1897); "The Wild Fowl of the United States and British Possessions, or the Swans, Geese, Ducks and Mergansers of North America" (8vo, New York, 1898).

Dr. Elliot was one of the founders of the American Ornithologists' Union (1883), its president for two years (1890-1891), and an active member of its council for twenty-eight years (1887-1915). He was also a member of the British Ornithologists' Union, the Zoological Society of London, a fellow of the Royal Society of Edinburgh, and an honorary or corresponding member of many scientific societies in Europe as well as in America.

In the early years of the founding and organization of the American Museum of Natural History Dr. Elliot greatly aided the trustees by his wise scientific advice-at that time the only resident naturalist in New York equipped with the requisite experience and technical knowledge-and acted as their agent for several years in Europe in the pur- 
chase of the important collections which formed the foundation of its present strong departments of mammalogy and ornithology. $\mathrm{He}$ has in later days shown his keen interest in its welfare through valuable gifts and appreciated advice.

On the occasion of his eightieth birthday, the American Museum made public recognition of his services through the publication of a brief biographical sketch of Dr. Elliot with portraits of him at the age of thirty years, at sixty-four (when curator of zoology at the Field Museum), and at eighty, and presented him with an engrossed memorial signed by the full scientific staff of the museum, giving him "greeting with grateful recognition and appreciation" of his services "as an expert adviser of the museum in its early days." A few months later he was elected to the board of trustees, from which his sudden removal by death is regarded as a great loss to the institution.

Dr. Elliot was not without further special honor in his home city. On March 24, 1914, the Linnæan Society of New York held a dinner in his honor in recognition of " his unique attainments in mammalogy and ornithology," at which the society presented him with its Linnæan medal of honor, the second occasion of the presentation of this medal. Dr. Elliot's speech of acceptance was in his characteristically graceful and happy vein. It was soon after published by the society as a special brochure.

Dr. Elliot was a man of striking personality, dignified and reserved in manner, conservative yet broadminded, constant and sympathetic in his personal friendships. His career was one of ceaseless activity in his lines of special research, and he has left many monuments to lighten the way of those who may follow in his footsteps. He fell into no ruts of routine that materially hampered his progress. On leaving England he was naturally deeply embued with the ways and methods of his British confrères, particularly in certain nomenclatorial matters, but these he was able to promptly abandon, accepting in their place the then radical innovations that had arisen in his home land during his absence. In other words, he soon accepted the A. O. U. Code of Nomenclature, with the date of Linné at 1758 instead of 1766 , its trinomialism, and the point of view regarding species and subspecies thus entailed, which many of his colleagues of the earlier days of his sojourn abroad could never bring themselves to adopt.

Dr. Elliot was the fourth son of George T'. and Rebecca Giraud Elliot. He was descended on his father's side from old Connecticut stock which settled near New London early in the sixteenth century, and on his mother's side from French ancestors who settled at New Rochelle and later moved to New York some two centuries ago. On the paternal side his forebears were prominent in public affairs, and in the colonial wars against the Indians. $\mathrm{He}$ was married in 1858 to Annie Eliza Henderson, by whom he had two daughters, of whom one, Margaret Henderson Elliot, still survives.

$$
\begin{aligned}
& \text { J. A. Allen } \\
& \text { American Museum of Natural History, } \\
& \text { New York }
\end{aligned}
$$

\section{FRANCIS MARION WEBSTER}

SCIENCE has suffered an irreparable loss and the entomological confraternity a severe shocis in the death, by pneumonia, of Professor F. M. Webster, in charge of cereal and forage insect investigations in the U. S. Bureau of Entomology. The sad event occurred on January third at Columbus, Ohio, where he had gone in order to attend the meetings of the American Association for the Advancement of Science.

Francis Marion Webster was born at Lebanon, New Hampshire, August 8, 1849, and was therefore in his sixty-seventh year. His first entomological writing occurred in the Chicago Weekly Interocean, July 2, 1874, under the title of "Notes on Some of the Common Injurious Insects." $\mathrm{He}$ was appointed assistant state entomologist of Illinois in 1882 and served in that capacity until 1884, publishing several short but interesting and important papers on insects affecting cereal and forage crops. Professor Webster served 